\title{
Design of Egg Incubator Based-Palm Oil in Bokonzi City (Sud Ubangi Province), Democratic Republic of the Congo
}

\author{
Philippe Ebuma Dongo', JB Zanyako Bosanza ${ }^{2}$, Damas Boboy Manzongo ${ }^{3}$, Benjamin \\ Zoawe Gbolo $^{4}$, Amédée Kundana Gbatea ${ }^{5}$, Muhammad Ridwan ${ }^{6}$, Koto-te-Nyiwa \\ Ngbolua $^{7 *}$ \\ ${ }^{1,2,3}$ Higher Institute of Agronomic Studies (ISEA) of Bokonzi, P.O. Box 67 Gemena, Democratic Republic of \\ the Congo \\ ${ }^{2}$ Faculty of Agricultural Sciences, University of Gbado-Lite, P.O. Box 111 Gbado-Lite, Democratic Republic \\ of the Congo \\ ${ }^{3}$ Protestant University of Ubangi (UPU), Centre IPOK, P.O. Box 140 Gemena, Sud Ubangi, Democratic \\ Republic of the Congo \\ ${ }^{4,5,7}$ Department of Environmental Sciences, University of Gbado-Lite, P.O. Box 111 Gbado-Lite, Democratic \\ Republic of the Congo \\ ${ }^{4,7}$ Department of Biology, Faculty of Sciences, University of Kinshasa, P.O. Box 190 Kinshasa XI, \\ Democratic Republic of the Congo \\ ${ }^{6}$ Universitas Islam Negeri Sumatera Utara, Indonesia \\ jpngbolua@unikin.ac.cd
}

\begin{abstract}
A trial was conducted in 2017 at the Higher Institute of Agronomic Studies (ISEA) in Bokonzi with the aim of setting up an egg incubator using palm oil-based combustion as an energy source to produce chicks. During 21 days of hen egg incubation in this tool, temperatures varied between 36.8 and $40^{\circ} \mathrm{C}$ with a minimum of $35.8^{\circ} \mathrm{C}$ (day eight) and a maximum of $40.5^{\circ} \mathrm{C}$ (day three and fifteen). Although the temperature values $\left(40.5^{\circ} \mathrm{C}\right)$ are slightly high with consequences on egg hatchability, the range of temperatures recorded during this study is within the acceptable threshold previously outlined by other researchers for hen egg incubation. Thus, with the daily frequency of 3 to 4 egg turnings, the hatchability rate reached $75 \%$. This result is consistent with the values previously obtained by other researchers, i.e. 65 to $75 \%$. In addition, in terms of production costs, the palm oil heated incubator proved to be superior, resulting in a $79.6 \%$ reduction in fuel costs compared to some types of oil heated incubators. This reflects a relative benefit of 875 Congolese Francs (or 0.53USD) per chick produced. This simple technology, using an available energy source, appears to be more adapted to the income of farmers and to the needs of rural communities where hydroelectric and thermal energy sources (oil and gas that produce heat energy) are not accessible at all.
\end{abstract}

Keywords: incubation; palm oil; hatching; eggs; Bokonzi

\section{Introduction}

In spite of its floristic, faunal, halieutic, agricultural and subsoil potentialities qualified even as a geological scandal, the Democratic Republic of Congo is also the country under the tropics abounding in malnourished people among whom there are more children under the age of 5 who are stunted in their growth and thus suffer from chronic malnutrition (Chausse et al., 2012). To cope with this malaise, which has become exponentially more acute in recent decades, many populations are engaged in agriculture, hunting, gathering non-timber forest products and raising domestic animals, including poultry, which is a quick way to increase meat production. The latter plays important socio-economic and socio-cultural functions (Keambou et al., 2009). Thus, for galliculture, the need for meat being an emergency, the industrial breeding system must be favored; 
unfortunately the gaze of our government is not yet focused on this aspect. The populations are more devoted to farm breeding based on small numbers of livestock: local breed chickens in extensive system following two first methods of backyard poultry rearing, according to the definition of the Food and Agriculture Organization of the United Nations (FAO), namely the traditional free-range system (from 1 to 10 birds), the improved free-range system (from 5 to 50 birds) and the small-scale confined system (from 50 to 200 birds (Kok et al., 2011). In most cases, the hens incubate the eggs. This natural incubation is only the right solution if the chicks are simply intended to replace old hens, as a hen incubates 8-14 eggs at a time and her annual production is limited to 30-90 eggs. After the 3 weeks of incubation and raising the chicks, the hen starts lying again for a period of 8 to 10 months. Under normal conditions, she has a lifespan of 5 years (Kok et al., 2011). However, if a larger number of eggs are to be hatched at the same time, it will be necessary to equip an incubator that requires the use of oil, gas or electricity supplied by a hydroelectric source or a solar panel. Unfortunately, these sources of energy are not accessible to the majority of the country's population, especially in rural areas. It is indeed in this optic that the present study is circumscribed which tries to produce chicks via an artisanal incubator using palm oil combustion as energy source. This is similar to the promotion of the use of an incubator using the heated rice husk technique in Bangladesh (Rajiur, 2013). To achieve this, this work wants to address the following main concern: Will the energy produced from the live burning of palm oil, even without incorporating a thermostat to regulate the temperature of the homemade incubator give a better hatching rate of chicks and thus reduce their production cost? The nature of the hens as a good incubator and the functioning of a modern incubator, electric, oil or gas automatic or semiautomatic constitute the starting point of this innovation which proposes to update a more adapted and simple device to the profit of the basic communities and especially those of the rural environment whose success will cause the blooming of the galliculture in order to make available the meat and the eggs at the good market..

\section{Research Methods}

The trial was conducted, in 2017, at the Higher Institute of Agronomic Studies (ISEA) of Bokonzi, located in Bokonzi Group, Sector of Bomboma, and territory of Kungu (Fig. 1), Province of South Ubangi in the Democratic Republic of Congo. Bokonzi is located at $2^{\circ} 20^{\prime} \mathrm{N}$ latitude and $18^{\circ}$ to $19^{\circ} \mathrm{E}$ longitude, altitude: $350 \mathrm{~m}$.

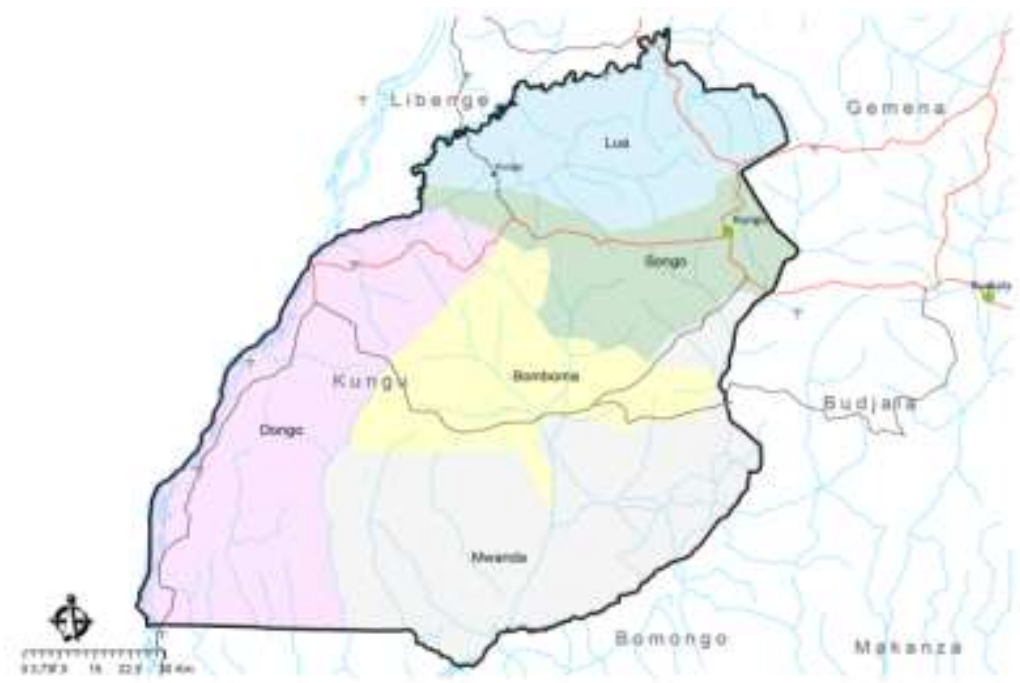

Figure 1. Map of Kungu Territory (Source: CAID, 2017) 
Two categories of materials were used in this study: biological and non-biological materials. The biological material consisted of clean eggs, collected from farmers who raise hens of the local breed (unidentified strain) in extensive system. A total of 50 hatching eggs weighing 50-60 g each were selected given that the weight of the chick is $2 / 3$ of that of the hatching egg (Bolondombe, 2006). In addition, small-gauge eggs (45$52 \mathrm{~g}$ ) have the lowest hatching rate compared to medium $(53-55 \mathrm{~g})$ and large $(56-69 \mathrm{~g})$ eggs regardless of strain (Aichouni et al., 2017). To avoid embryonic mortalities, these eggs were stored at room temperature with the air chamber on top and less than a week before incubation, following the recommendations of Kok et al. (2011). As for the non-biological material, it was formed by an incubator designed by hand using local materials, namely: iron bar (from recycling) which served as a heat conductor [iron being among the good conductors of heat and electricity (Jodogne \& Dessart, 1971), empty milk cans (used as oil jars); wicks of clothing fabric to produce flame, sieve to collect eggs to be hatched; triplex wood (to form the walls of the incubator) and sawdust (to fill both walls as a bad conductor of heat the thermometer (to control the temperature). Locally produced palm oil was used as fuel or energy source for the incubator while water was used to regulate the humidity in the incubator.

Finally, three mercury thermometers graduated in Celsius degree were used for temperature control during incubation. The handmade incubator, composed of two walls, was mainly made with rudimentary inputs locally available to farmers, namely triplex and white wood. The inner wall was formed by a $3 \mathrm{~cm}$ thick frame and $1 \mathrm{~cm}$ thick slats. This wall had a length of $50 \mathrm{~cm}$, width and height equal to the $2 / 3$ of length, or $33 \mathrm{~cm}$. For the external wall, it was formed by a $5 \mathrm{~cm}$ thick frame and $1.5 \mathrm{~cm}$ thick slats. This wall had a length of $70 \mathrm{~cm}$, a width and a height equal to the $2 / 3$ of length that is $46 \mathrm{~cm}$. The sealing of the inner wall was obtained with the help of wallpapers in order to limit the escape of heat (temperature loss) and the two walls were separated sawdust (bad heat conductors) to limit the influence of the environmental temperature.

For the energy source, this study used live combustion of palm oil (in its raw state), iron bar as a good heat conductor in the inner wall enclosure. The use of palm oil is justified by the promotion of a technology adapted to the income of the farmers, allowing the use of crude vegetable oil as a less expensive fuel, given that the farmers do not have access to electrical energy. This form of energy makes it possible to launch a large-scale development program because there will be no dependence on foreign markets (Quenum, 1989). The incubator was placed in a room constructed from inexpensive materials (wood and straw) that could be obtained locally. The room had a door and two windows that could be closed to regulate the temperature of the room and, hence, the incubator. Since the incubator should never be completely closed because the embryo in the egg needs heat, air, moisture and movement to become a chick (Wageningen et al., 1999), the experiment began with a dry run to control the temperature setting before placing eggs in the incubator (Kok et al., 2011). For the blank test, it took at least 6 hours to heat the incubator before loading the eggs to allow the incubation temperature to be raised and maintained between $37^{\circ}$ and $39^{\circ} \mathrm{C}$. Once the brooding temperature was reached, the eggs could be loaded into the incubator. In the incubator, the eggs were laid flat on their sides on a sieve placed 15 $\mathrm{cm}$ below the iron blade likely to diffuse heat and $5 \mathrm{~cm}$ above the wet sand tray (source of humidity) until hatching on day 21. The frequency of temperature sampling was 3 to 4 times a day and once at night using a medical thermometer placed in direct contact with the eggs. Assessment and control of thermal fluctuation were strict observations. The eggs were turned 3 to 4 times during the day (at 6:00', 12:00' and 18:00') and sometimes once at night to allow homogenization of the temperature in the egg and consequently promote the 
proper development of the embryo because according to previous work, this practice plays a favorable role in preventing the yolk from adhering to the shell membrane and leading to the mortality of the embryo through dehydration (Rajiur, 2013). As candling is an operation that allows the detection of infertile eggs and dead embryos, for this test, it was performed on the 3rd and 14th day of incubation because it is during this period that the embryo is well formed. According to Cherifi (2008), this technique allows not only to determine if an egg is cracked before incubation and if it is fertile from the 7th day, but also the viability of the embryo during incubation: we can observe the good development of the air chamber at the 7th, 14th and 19th day of incubation and eliminate the eggs containing the dead embryo during incubation. It is carried out with any lamp, the egg to be examined being put between the eye of the tester and a source of quite powerful light in a relatively dark room to observe the fertilized egg, i.e. the one which presents a dark point from which irregular lines (blood vessels) leave (Kok et al, 2011). Temperature variation during incubation, hatching rate, activity cost (fuel loads) were the main analyzed parameters in this study.

- The temperature during incubation. For the verification of temperature in order to observe the good functioning of the apparatus, marked by the good progress of the development of the embryo and the obtaining of better rate of hatching (Wageningen and al., Op cit.), each time, the turning of the eggs was preceded by the taking of the temperature for the above mentioned reasons.

- The hatching rate is the ratio of the number of eggs hatched to the total number of eggs minus broken eggs, eggs whose embryogenesis had stopped during incubation, eggs whose chicks died during egg turning or clear eggs that escaped the first candling. This hatching rate (in \%) is calculated using the formula of Putt et al. (1987) quoted by Kalambaie et al. (2003) namely

$$
\text { Hatching rate }=\frac{\text { Number of hatched eggs }}{\text { Total number of eggs }- \text { eggs lost }} \times 100
$$

It should be noted that the hatching rate explains the percentage of chicks hatched from incubated eggs, also in relation to the fertilization rate (Cherifi, Op cit.).

- Cost of the activity: As the incubator was made from local/traditional materials, the different variable costs retained for the incubation of eggs during this study were limited to the purchase of palm oil used as fuel and energy source.

\section{Discussion}

The temperature fluctuation due to the live combustion of palm oil during the experiment is presented in figure 2 . 


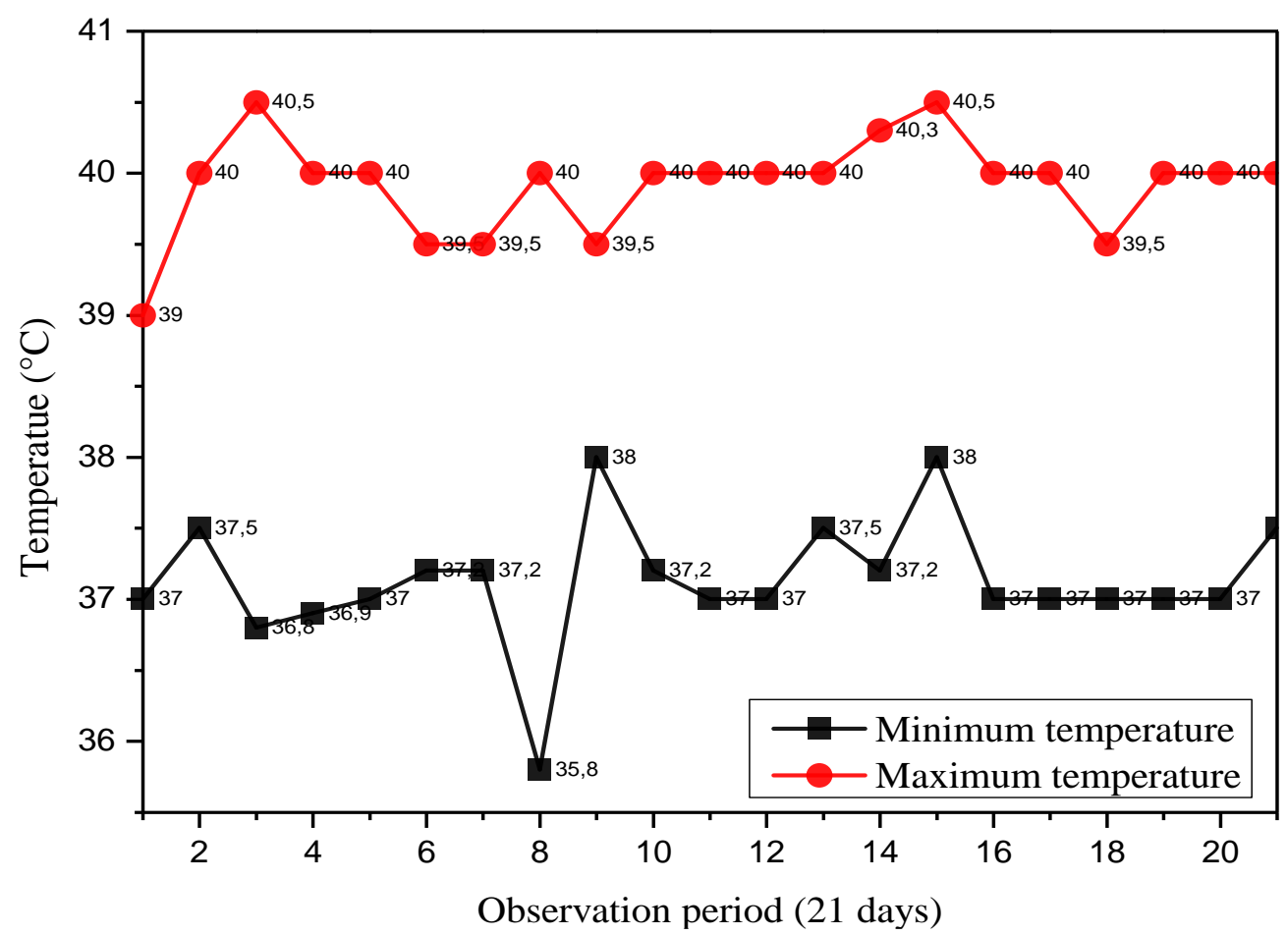

Figure 2. Variation of Temperature during the Test

This figure shows that throughout the experiment, the temperature varied between 36.8 and $40^{\circ} \mathrm{C}$ with a minimum of $35.8{ }^{\circ} \mathrm{C}$ (day eight) and a maximum of $40.5{ }^{\circ} \mathrm{C}$ (day three and fifteen). Although the maximum temperature on the third day was sometimes slightly higher than Rajiur's (Op cit.) that a constant temperature should be maintained between $36.5{ }^{\circ} \mathrm{C}$ and $37.5{ }^{\circ} \mathrm{C}$, the range of temperatures recorded during this study is within the acceptable threshold previously emphasized by other researchers who recommend never to exceed the temperature of 37 to $39^{\circ} \mathrm{C}$; because an excess of temperature $\left(40{ }^{\circ} \mathrm{C}\right.$ during a few hours) can be fatal or damaging often leading to the obtaining of chicks with malformations (Bolondombe, Op cit; Kok et al., Op cit.). Moreover, Saveur (1988) cited by Cherifi (Op cit.) underlines that a temperature of the order of $38,5{ }^{\circ} \mathrm{C}$, accelerates the embryonic development by advancing the date of the hatching to 19,5 days; whereas a lower temperature $\left(35,5{ }^{\circ} \mathrm{C}\right)$ delays it to 23 days. This observation on the effect of low temperature was also made by Secaar (Op cit.).

The results of hatching rates are recorded in the table below.

Table 1. Evaluation of Hatching Rate

\begin{tabular}{|c|c|c|c|c|c|c|}
\hline \multicolumn{5}{|c|}{ Number of eggs } & \multicolumn{2}{l|}{ Rate (\%) } \\
\hline Incubated & Broken $^{(1)}$ & Clear $^{(2)}$ & Fertile & Hatched & Fertility & Hatching \\
\hline 50 & 04 & 06 & 40 & 30 & 80 & 75 \\
\hline
\end{tabular}

Legend: (1) eggs broken during handling; ; (2) clear eggs having escaped the 1st candling

In view of this table, the results attest that during this investigation, the accuracy of candling gave a fertility rate of $80 \%$ and with the daily frequency of turning the eggs 3 times and 4 times, the hatching rate reached $75 \%$ of fertile eggs. 


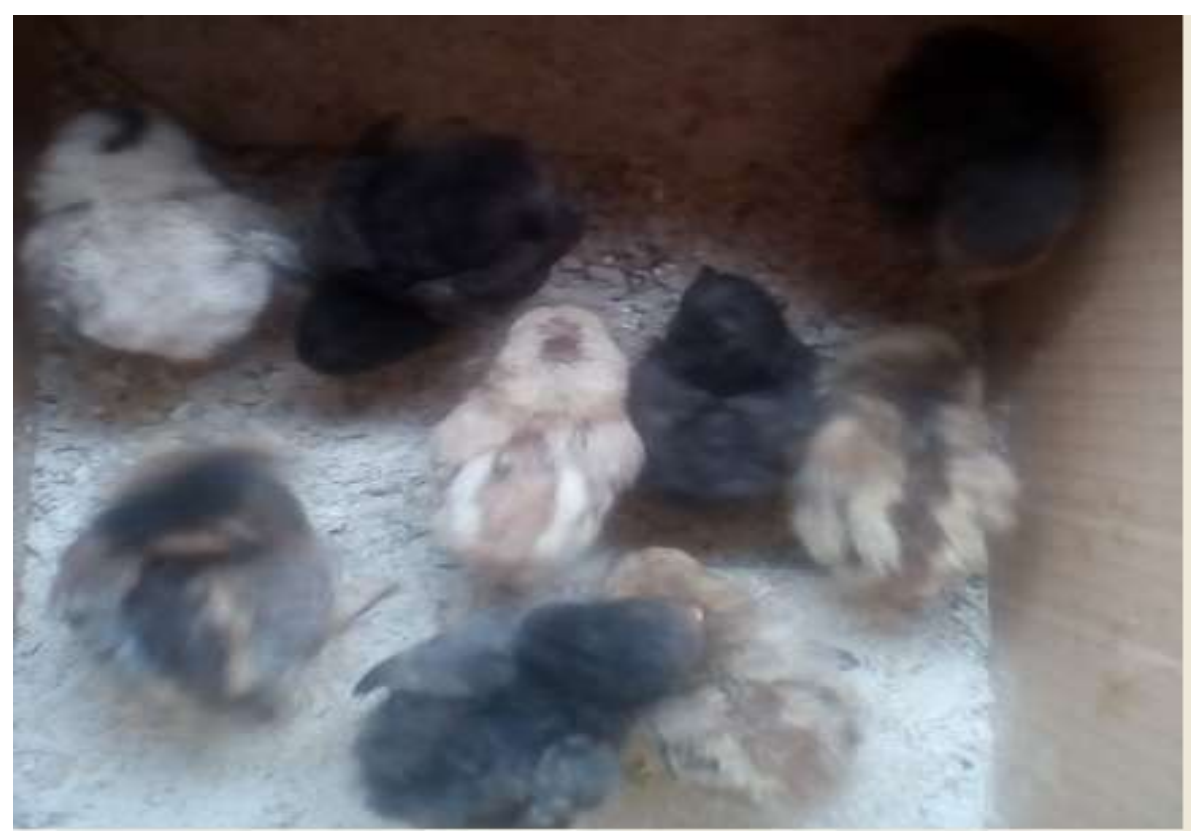

Figure 3. Products of the Palm Oil Heated Incubator: One Week after Hatching and Fed Maize Meal and Rice Bran

The results of this study corroborate those reported in previous literature related to this study, which found an artificial hatching rate in the range of 65-75\% (Kiatoko, 1990; Nyongombe, 2001), as it is not common to reach $80 \%$ or more with home-built incubators (Kok et al., Op cit.). Indeed, the hatching rate achieved in this study is higher than those reported in the previous literature including: $41.7 \%$ obtained by Seydou (2011) in Burkina Faso for local hens with the solar incubator; $64.7 \%$ obtained in Kenya in the rural breeding of Mwatate, with a small simple incubator with a capacity of 50 eggs, heated with a kerosene lamp and equipped with a single control device (a thermometer) and whose results were as follows: of the 20 eggs placed in the incubator, 11 hatched, 6 embryos died, 2 eggs were unfertilized and 1 broke. Similarly, in a study done in Algeria, Haddadi \& Hadj-Ali (2017) report a lower hatching rate of 62\% with a REAL 49 automatic series incubator with a capacity of 49 eggs. Similarly, Keambou et al. (2009) also obtained a rate of $62.3 \%$ in a rural area in a study in which local chicken eggs were artificially incubated to produce chicks. Kok et al. (2011) also report that normal hatching rates are between 50 and $70 \%$, quite close to that of our trial. However, this rate is slightly lower than that obtained in Yaoundé, Cameroon where an experienced farmer had built an incubator with a capacity of 70 eggs in a television set that he had equipped with a purchased thermostat; out of 50 eggs incubated 40 hatched on days 21 and 22 and 10 unincubated eggs of which 2 contained dead embryos, 2 had cracked and 2 were infected (Wageningen et al., Op cit.).

The mortality recorded (25\%) could also be due to high temperatures of 40.5, 40.2 and $40.5{ }^{\circ} \mathrm{C}$ reached on the third, fourteenth and fifteenth day respectively, due to the lack of a thermostat, as many researchers testify that above $40{ }^{\circ} \mathrm{C}$ the heat kills the embryos (Bolondombe, Op cit.). In addition, like Haddadi \& Hadj-Ali (2017), this mortality can probably be attributed to the unfavorable conditions of obtaining eggs for hatching, resulting in infertility, early and late embryonic normalities; considering the extensive system of chicken rearing in the region. Considering only the value of the energy source to operate this incubator, 13.5 liters of palm oil were consumed to produce 30 chicks (male and female) after 21 days. This means that each chick cost about 0.45 liters of oil. In value 
terms, with a price of 500 Congolese francs/liter of palm oil (at an exchange rate of 1 USD $=1,650 \mathrm{CDF})$ in the study area, each chick cost about 225 Congolese francs or 0.14USD. Similar assessments by Wageningen et al. (Op cit.) and Kok et al. (Ibid.) revealed that a kerosene-fired incubator requires about half a liter of kerosene per 24 hours, and for 40 incubated eggs yielding 28 chicks after 21 days, each chick cost about 0.5 liter of kerosene. Considering the price of 2200 Congolese Francs/liter of oil (exchange rate of 1 $\mathrm{USD}=1,650 \mathrm{CDF}$ ), a chick costs about 1,100 Congolese Francs/chick (i.e. 0.67USD). Compared to this type of incubator, the palm oil heated incubator proves its superiority resulting in a $79.6 \%$ reduction in fuel costs. This corresponds to a relative advantage of 875 Congolese francs (0.53USD) per chick produced.

\section{Conclusion}

The purpose of this investigation was to set up an incubator using palm oil-based combustion as an energy source to produce chicks. Thus, the eggs of the hens collected from the farmers in Bokonzi were placed in an incubator designed by hand and using the energy source produced from the live combustion of palm oil, without incorporating a thermostat. After observations, it appears that this type of incubator allowed the production of chicks after 21 days. Although the temperature values $\left(40.5{ }^{\circ} \mathrm{C}\right.$ on the third and fifteenth day) are slightly high for incubation in general with consequences on the hatching rate, the range of temperatures recorded (between 36.8 and $40{ }^{\circ} \mathrm{C}$ ) during this study is within the acceptable threshold previously emphasized by other researchers who recommend never exceeding the temperature of 37 to $39^{\circ} \mathrm{C}$ for the incubation of hen eggs. Thus with the frequency of 3 and 4 egg turnings, the hatching rate reached $75 \%$. Value corresponding to the results previously obtained by other researchers. In addition, with regard to production costs, the palm oil heated incubator proved to be superior, resulting in a $79.6 \%$ reduction in fuel costs, compared to some types of oil heated incubators. This translates into a relative advantage of 875 Congolese Francs (or 0.53USD) per chick produced. Considering the above results, this simple technology, using an available energy source, appears to be more adapted to the incomes of farmers and to the needs of rural communities where hydroelectric and thermal energy sources (oil and gas that produce heat energy) are not at all accessible.

It is worth suggesting that further studies consider other parameters, such as humidity and ventilation within this system, to continually increase the egg hatching rate and thus extend the activity to eggs of other poultry species, such as ducks and guinea fowl commonly raised in rural areas.

\section{References}

Aichouni A, Siloum S, Mekci S (2017). Effet du calibre et de l'origine de l'œuf sur le taux d'éclosion et la qualité du poussin chair. Nature \& Technologie. B : Sciences Agronomiques et Biologiques $16: 92-53$.

Bolondombe WY (2006). Construction zootechnique. Cours universitaire, IFA YANGAMBI

CAID (2017). Territoire de Kungu. Fichier du territoire (mise à jour le 31 mars 2017). Cellule d'Analyses des Indicateurs de Développement, Primature, République démocratique du Congo. https://www.caid.cd.

Chausse JP, Kembola T, Ngonde R (2012). L'agriculture : pierre angulaire de l'économie de la RDC. Dans : Johannes Herderschee, Daniel Mukoko Samba et Moïse 
Tshimenga Tshibangu (éditeurs), Résilience d'un Géant Africain : Accélérer la Croissance et Promouvoir l'Emploi en République Démocratique du Congo, Volume II : Etudes sectorielles, MÉDIASPAUL, Kinshasa, pp1-97.

Cherifi Z (2008). Etude des performances zootechniques de quelques élevages de reproducteurs chaires du Groupe Avicole Centre. Mémoire en vue de l'obtention du diplôme de magister en sciences agronomiques, Institut National Agronomique (Science animale), EL ARRACH-ALGER. 107p.

Haddadi A, Hadj-Ali A (2017). Incubation des œufs dans un élevage fermier de BOUINANE à l'aide d'une couveuse automatique. Institut Supérieur des sciences Vétérinaires-Blida, Université Saad Dahlab-Blida 1.

Jodogne J, Dessart A (1971). Chimie minérale, édition A. de Boeck-Bruxelles, Belgique.

Kalambaie M, Mwamasaka B, Yav LJC (2003). Etude des contraintes socio-économiques à la production et à la commercialisation de la volaille (cas du canard et de pintade). Annales de la Faculté des Sciences de l'Université de Kisangani, 424-434.

Keambou TC, Boukila B, Moussounda G, Manjeli Y (2009). Comparaison de la qualité des œufs et des performances de croissance des poussins locaux des zones urbaines et rurales de l'Ouest-Cameroun. Int. J. Biol. Chem. Sci. 3(3): 457-465.

Kiatoko MH (1990). Zootechnie. Cours Universitaire, IFA-YANGAMBI (Inédit).

Kok E., De Feyter J. et Vink A. (2011). Amélioration de lincubation et de l'élevage des poussins. Sixème édition (revue). Agrodok 34. ISBN Agromisa: 978-90-8573-115-3 ; ISBN CTA: 978-92-9081-400-9

Nyongombe UN (2001). Zootechnie. Cours Universitaire, IFA-YANGAMBI (Inédit).

Quenum BM (1989). Vivre la terre et prospérer In-Biénergies G1/1G1/18 : édition Hytrop, me Saint-Victor 3.5200HUY : Belgique.

Rajiur Rahman SM (2013). Fabriquer et exploiter un mini-couvoir (méthode avec bac à sable). Bangladesh : Fonds international de développement agricole ; Palli KarmaSahayak Foudation. 19p.

SECAAR (Service Chrétien d'Animation Rurale) (s.d.). Construire son incubateur à pétrole. Diffusé par: SECAAR - 06 B. P. 2037 - Abidjan 06 - CÔTE D'IVOIRE

Seydou Y (2011). Etude des performances d'une couveuse solaire dans lincubation des œufs de poule (Gallus gallus). Memoire de fin de cycle en vue de l'obtention du diplôme d'Ingenieur du Developpement Rural. Institut du Developpement Rural, Université Polytechnique de BOBO-DIOULASSO. 58p. (Inédit).

Wageningen NV, Meinderts J, Bonnier P, Kasper H (1999). L'incubation des oeufs par les poules et en couveuse. Agrodok $\mathrm{n}^{\circ} 34$, quantième édition (revue). Editions Fondation Agromisa et CTA, Wageningen, Pays Bas, 61 p.. ISBN : 90-77073-37-x. 